\title{
JARINGAN PERDAGANGAN BERAS DAN DINAMIKA PELABUHAN EKSPOR DI SULAWESI SELATAN PADA 1930-AN
}

\section{RICE TRADE NETWORK AND \\ EXPORT PORT DYNAMICS IN SOUTHERN SULAWESI \\ IN THE 1930s}

Syafaat Rahman Musyaqqat

Universitas Indonesia

Jln. Cengkeh No. 5G, Pondok Cina, Beji, Depok, Jawa Barat, Indonesia

syafaatrahman04@gmail.com

Diterima tanggal 20 Januari 2021

Disetujui tanggal 25 Mei 2021

\begin{abstract}
As the National rice barn, the Southern Sulawesi is often associated with the green revolution of the New Order Regime, especially since Indonesia succeeded the rice self-sufficency in 1984. Furthermore, Southern Sulawesi has an important role as rice supplier in Indonesia which was proven in 1930s. The state control is one of main factors supporting Southern Sulawesi's success, along with another factor particularly environmental conditions and irrigation development. This article discusses the rice trade network and its relationship to the dynamics of export ports in Southern Sulawesi in the 1930s. By applying the historical method, this study employed primary sources, such as archives, journals, newspapers, and magazines. The findings show that the rice trade during the 1930s experienced a significant development as the state involved in the trade in 1933. The increase was seen in the trading system and the amount of exported rice. The increase which was seen in the trading system and the amount of exported rice indicates the significance of Southern Sulawesi as one of the rice barns in the Dutch East Indies. By describing the production areas, involved actors, export ports, and trade networks, this study shows the relationship between intra-and inter-regional trade.
\end{abstract}

Keywords: Southern Sulawesi, the rice trade, state control, and port dynamics.

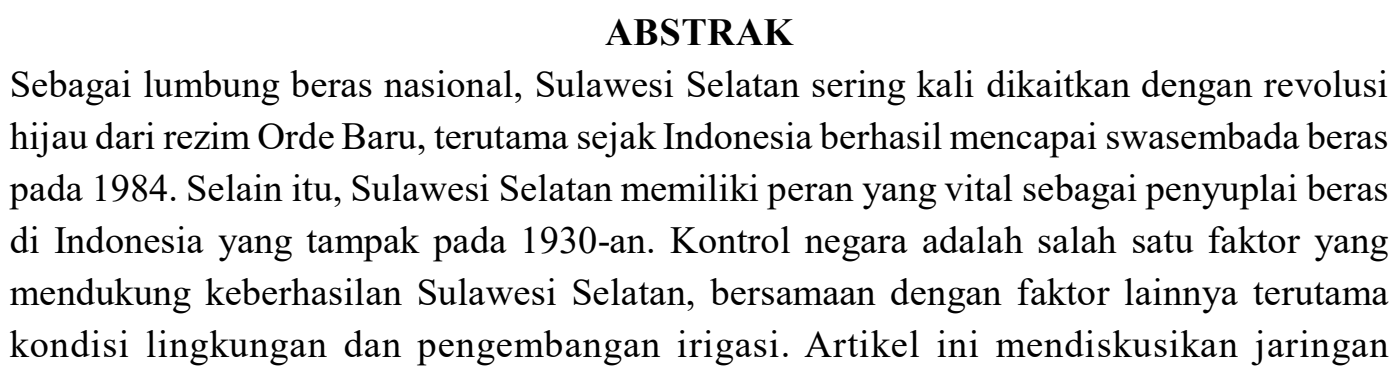

DOI: $10.33652 /$ handep.v4i2.157 
perdagangan beras dan hubungannya dengan dinamika pelabuhan ekspor di Sulawesi Selatan pada 1930-an. Dengan menerapkan metode sejarah, studi ini memanfaatkan sumber-sumber primer, seperti arsip, jurnal, koran, dan majalah. Temuan studi menunjukkan bahwa perdagangan beras selama 1930-an telah mengalami perkembangan yang signifikan seiring keterlibatan negara dalam perdagangan pada 1933. Peningkatan ini terlihat dalam sistem perdagangan dan jumlah beras yang diekspor. Peningkatan yang tampak dari sistem perdagangan dan jumlah beras yang diekspor menjelaskan signifikansi Sulawesi Selatan sebagai salah satu lumbung beras di Hindia Belanda. Dengan menggambarkan daerah produksi, aktor-aktor yang terlibat, pelabuhan ekspor, dan jaringan perdagangan, studi ini memperlihatkan hubungan antara perdagangan intraregional dan interregional.

Kata kunci: Sulawesi Selatan, perdagangan beras, kontrol negara, dan dinamika pelabuhan.

\section{A. PENDAHULUAN}

Pada 23 Oktober 2019, Joko Widodo, Presiden Republik Indonesia, dikabarkan telah menetapkan Syahrul Yasin Limpo untuk menduduki jabatan pemerintahan sebagai Menteri Pertanian dalam Kabinet Indonesia Maju periode 2019-2024 (Ihsanuddin 2019). Dengan penetapan itu, nahkoda pertanian di Indonesia untuk kedua kalinya secara beruntun dijabat putra daerah asal Sulawesi Selatan. Sebelumnya, posisi Menteri Pertanian ditangani Amran Sulaiman (menjabat 2014-2019).

Sementara itu, dalam warta lain, Badan Pusat Statistik merilis data mengenai hasil produksi beras di Indonesia pada 2019. Berdasarkan data itu, jumlah produksi beras nasional disebutkan telah mencapai 31,31 juta ton. Dari jumlah ini, Sulawesi Selatan menghasilkan produksi beras sebanyak 2.899.575 ton. Angka ini menempatkan Provinsi Sulawesi Selatan berada di urutan keempat sebagai lumbung beras di Indonesia, setelah Provinsi Jawa Tengah di urutan pertama, Jawa Timur di urutan kedua, dan Jawa Barat di urutan ketiga (Anon 2020). Pada hakikatnya, kedua warta tersebut sekiranya menjadi petunjuk kuat yang meneguhkan relasi antara Sulawesi Selatan dan lumbung pangan di Indonesia saat ini.

Kendati demikian, fenomena tersebut sesungguhnya bukan suatu hal yang baru. Paling tidak sejak awal abad ke-20, Pulau Sulawesi telah berkedudukan sebagai pusat perniagaan beras di bagian timur Kepulauan Nusantara (Touwen 2001). Posisi itu menunjukkan suatu hal yang menarik dalam sejarah perdagangan beras di Hindia Belanda.

Di satu sisi, sekalipun Jawa terkenal sebagai "pulau beras", namun praktik impor beras di Hindia Belanda telah berlangsung rutin sejak 1860-an (Mansvelt 1978). Beras impor didatangkan dari daratan Asia Tenggara, seperti Thailand, Burma, dan Indocina. Sebelum Perang Dunia I, total produksi di ketiga wilayah yang dikenal sebagai pengekspor beras utama di Asia Tenggara mencapai empat juta ton setiap tahunnya (An 2011).

Ketika itu, terdapat banyak faktor yang memungkinkan berlangsungnya praktik impor beras. Di samping 
ancaman gagal panen dan rendahnya pemahaman para petani dalam teknik pengolahan padi secara optimal, faktor lainnya ialah perkembangan transportasi berupa pengenalan kapal uap, sehingga biaya pengangkutan komoditas menjadi lebih murah.

Perlu diketahui, menjelang akhir abad ke-19, beras adalah makanan pokok untuk sebagian besar masyarakat di Kepulauan Nusantara, sekalipun jagung dan sagu masih menjadi bahan makanan utama di beberapa tempat, seperti Madura, Irian Jaya, dan Maluku (Eng 1996). Dengan kondisi itu, kebutuhan beras domestik tentunya semakin meningkat. Hal ini sejalan dengan peningkatan konsumsi beras impor. Jika impor beras masih tercatat sebanyak $6,8 \%$ dari total nilai impor Hindia Belanda pada 1874-1875, maka pada 1896-1900 impor beras telah mencapai $8,4 \%$ dari total nilai impor. Alih-alih semakin berkurang, suntikan beras impor terus meningkat memasuki awal abad ke-20, yakni sebanyak 13,7\% dari total nilai impor pada 1901-1905 (Kano 2008:47). Aktivitas impor beras di Hindia Belanda tetap berlangsung hingga 1930-an, sekalipun upaya pengembangan pertanian semakin digiatkan seiring penerapan politik etis pada 1901.

Di lain sisi, cerita yang sedikit berbeda tampak dari kondisi perberasan di Sulawesi Selatan. Sejak awal abad ke-20, pelabuhan Makassar semakin penting sebagai pusat distribusi bahan makanan impor, seperti beras dari Saigon dan Thailand, dan tepung dari Australia, yang kemudian dikapalkan langsung ke berbagai daerah di Indonesia bagian timur (Sutherland
2015:70). Walaupun demikian, dalam perkembangannya Sulawesi Selatan kemudian menjelma sebagai salah satu lumbung beras di Hindia Belanda. Keadaan ini berlangsung sepanjang 1930-an. Dalam periode itu, Sulawesi Selatan berhasil tampil sebagai daerah surplus beras sekaligus penyuplai beras ke daerah-daerah defisit beras, baik daerah luar Jawa maupun daerah Jawa.

Hal yang menarik ialah peranan Sulawesi Selatan tersebut cukup kontras dengan situasi yang tampak di daerah-daerah luar Jawa lainnya. Menurut Touwen (2001), sejak awal abad ke-20 kebutuhan beras untuk sebagian besar daerah luar Jawa cukup bergantung dengan suplai dari Jawa, di samping suntikan beras impor dari daratan Asia Tenggara. Sesungguhnya ada beberapa faktor yang saling berkelindan sehingga daerah luar Jawa belum sepenuhnya mampu memenuhi kebutuhan berasnya sendiri. Selain ketidaksuburan tanah dan konsentrasi budi daya komoditas ekspor, juga adanya kebutuhan yang meningkat guna memenuhi konsumsi tenaga kuli perusahaan Eropa.

Kendati demikian, Touwen tidak memungkiri adanya daerah-daerah di luar Jawa yang berperan sebagai penyuplai beras ke daerah Jawa dan daerah luar Jawa. Salah satu di antaranya ialah Sulawesi Selatan (Touwen 2001). Karena peran tersebut, tidak heran pula apabila Dick (1988) berkesimpulan bahwa beras adalah muatan komoditas yang dominan dalam perdagangan antarpulau sepanjang 1930-an. Pertanyaannya kemudian, faktor apa yang memungkinkan Sulawesi Selatan menjadi daerah 
Handep Jurnal Sejarah dan Budaya Vol. 4, No. 2, Juni 2021, hlm. 113-140

surplus beras pada 1930-an? Sejauh mana pengaruh campur tangan negara terhadap aktivitas perniagaan beras? Bagaimana pula jaringan perniagaan beras pada masa itu?

Tulisan ini bertujuan menguraikan jaringan perdagangan beras dan kaitannya dengan dinamika pelabuhan ekspor di Sulawesi Selatan pada 1930-an. Dengan mengetengahkan komoditas beras, topik ini dimaksudkan untuk melihat secara jelas peran Sulawesi Selatan dalam konteks ekonomi kolonial. Tulisan ini juga ingin memperlihatkan adanya keterkaitan antara perdagangan beras (Sejarah Ekonomi) dan dinamika pelabuhan (Sejarah Maritim). Selain itu, pasar beras domestik sesungguhnya tidak terputus sama sekali dengan pasar beras internasional selama 1930-an, sebagaimana akan dijabarkan nantinya.

Beberapa studi terdahulu telah mengkaji perniagaan beras di masa kolonial (Eng 1996; Kano 2008; Mansvelt 1978; Moeljono 1971). Walaupun demikian, berbagai kajian yang telah dilakukan para sarjana tersebut umumnya masih berfokus pada perdagangan beras di seluruh Hindia Belanda. Dengan mengambil Daerah Luar Jawa (Buiten Landen) sebagai unit kajian, Touwen menuturkan adanya keragaman dalam pengembangan ekonomi di daerah luar Jawa selama periode akhir pemerintahan kolonial (1900-1942). Alih-alih keseragaman, perbedaan kondisi lingkungan, termasuk kesuburan tanah, semakin mempertegas diversifikasi tersebut. Pada gilirannya, situasi itulah yang membuat perdagangan beras menempati posisi penting dalam ekonomi domestik selama era kolonial.

Dalam konteks kajian perniagaan beras di Sulawesi Selatan, dua tulisan mutakhir ditulis Nur (2017) serta Musyaqqat dan Pradjoko (2020). Tulisan yang disebut pertama mengulas dinamika perniagaan beras dengan fokus utamanya pada pelabuhan Makassar, sementara tulisan terakhir menekankan peran pelabuhan Parepare dalam perdagangan komoditas beras di Sulawesi Selatan pada 1930-an. Namun demikian, bagaimana hubungan perdagangan beras dan kaitannya dengan dinamika pelabuhan ekspor masih luput dari pembahasan kedua karya tersebut.

Kajian lainnya ialah studi Musyaqqat (2020). Dengan mengetengahkan perniagaan beras di Sulawesi Selatan pada 1930-an, ia berpendapat bahwa jaringan perniagaan beras saat itu adalah bentuk perjalinan warisan jalur rempah dan kuasa negara. Walaupun batasan spasial dan temporalnya sama dengan yang diusung artikel ini, namun Musyaqqat tidak menguraikan secara lebih detail mengenai peran Sulawesi Selatan sebagai lumbung beras dalam konteks ekonomi kolonial. Berbeda dengan tulisan Musyaqqat, artikel ini tidak hanya sekadar menganalisis perdagangan beras semata. Artikel ini juga berupaya menawarkan perspektif baru, terutama menyangkut adanya korelasi antara perdagangan beras (Sejarah Ekonomi) dan dinamika pelabuhan (Sejarah Maritim) selama periode tersebut. Dalam tulisan dengan tema yang berbeda, Musyaqqat dan Rahman 
(2020) menuturkan bahwa selama 1930-an tren global pariwisata yang melanda berbagai daerah di Hindia Belanda juga menyentuh Sulawesi Selatan. Berdasarkan tinjauan literatur yang telah disebutkan, tulisan ini diharapkan dapat melengkapi dan mengisi kekosongan yang sebelumnya luput dari perhatian para sarjana perihal perniagaan beras di Sulawesi Selatan pada masa kolonial.

Konsep "perdagangan beras" dalam tulisan ini diartikan sebagai bagian yang menghubungkan produsen pertanian di daerah dengan konsumen di kota ataupun di perdesaan daerah seberang. Dalam konteks sistem pertanian, perniagaan beras adalah hal yang penting untuk memahami proses menyeluruh mengenai sirkulasi beras mulai dari produsen hingga konsumen (Lee 2017). Dengan kedudukannya sebagai bahan pangan utama, kajian perberasan termasuk aspek mendasar dalam memahami dinamika ekonomi politik kolonial (An 2011), tidak terkecuali Asia Tenggara. Di samping itu, mengingat Indonesia merupakan negara laut utama yang ditaburi pulaupulau (Lapian 2009:2), aktivitas perniagaan beras pada dasarnya berlangsung dalam dua bentuk, yakni perniagaan darat dan laut (maritim). Khususnya di laut, beras adalah komposisi utama dalam perdagangan Asia sejak era prakolonial, baik dalam daerah (intraregional) maupun antardaerah (interregional) (Arasaratnam 1988). Bahkan, menurut Sulistyono (2001:223), beras adalah salah satu komoditas yang bersifat integratif dalam konteks perdagangan antardaerah, seperti yang terlihat dari kasus sejarah pelayaran perahu di sekitar kawasan Laut Jawa pada masa kolonial.

\section{B. METODE}

Sebagaimana lazimnya studi historis, artikel ini menggunakan metode sejarah. Metode ini terdiri dari beberapa tahap, antara lain heuristik, kritik, interpretasi dan historiografi (Gottschalk 1985). Pada tahap pengumpulan sumber (heuristik), penulis mencari dan mengumpulkan sumber primer, seperti arsip pemerintah kolonial, koran, jurnal, dan majalah. Sumber-sumber primer ini didapatkan di Arsip Nasional dan Perpustakaan Nasional Republik Indonesia. Di samping itu, beberapa sumber juga didapatkan dari website delpher.nl. Sumber yang dimaksud ialah Soerabaijasch Handelsblad dan Bataviaasch Nieuwsblad. Website lainnya ialah nationaalarchief.nl. Melalui situs ini, penulis memanfaatkan sebuah sumber sezaman yang berjudul Irrigatie Rapport van Celebes (1911). Sumber ini belum pernah digunakan sebelumnya dalam kajian perdagangan beras di Sulawesi Selatan. Adapun sumber sekunder berupa karya ilmiah yang berkaitan dengan topik studi turut dimanfaatkan dalam penulisan artikel ini.

Selanjutnya ialah tahap kritik. Berbagai sumber yang sudah dikumpulkan kemudian diverifikasi (kritik sumber), baik internal maupun eksternal, untuk menguji keautentikan dan kekredibilitasan sumber. Pada tahap ini, data ekspor beras yang 
ditemukan tidak jarang menunjukkan adanya perbedaan antara satu sumber dan sumber lainnya. Sebagai contoh ialah data mengenai ekspor beras di pelabuhan Palima pada 1932. Dalam memori serah terima jabatan pejabat Gubernur Selebes, jumlah ekspor beras di pelabuhan itu hanya sebesar 324 ton, sementara laporan yang sama dari Asisten Residen Bone mencatat jumlah yang jauh lebih banyak, yaitu 2.754 ton. Dari perbedaan ini, penulis menggunakan data yang termuat dalam memori serah terima jabatan Asisten Residen Bone dengan pertimbangan bahwa angka yang dimuat lebih valid. Selain itu, data yang dimuat dalam memori Gubernur Selebes kemungkinan besar hanya memuat jumlah beras di Makassar yang diekspor langsung dari pelabuhan-pelabuhan Bone, termasuk Palima. Karena itu, butuh sikap kehati-hatian dalam penggunaan data mengenai perdagangan ekspor beras.

Tahap berikutnya ialah interpretasi, tahap ini merupakan penentuan hubungan kausalitas antara berbagai data sejarah untuk menetapkan fakta sejarah. Bagian terakhir ialah historiografi. Pada tahap inilah berbagai fakta sejarah yang telah ditetapkan kemudian dirangkai ke dalam suatu tulisan yang sistematis dan utuh mengenai Jaringan Perdagangan Beras dan Dinamika Pelabuhan Ekspor di Sulawesi Selatan pada 1930-an.
Vol. 4, No. 2, Juni 2021, hlm. 113-140

\section{HASIL DAN PEMBAHASAN \\ 1. Kontinuitas Sulawesi Selatan sebagai Lumbung Padi}

Sulawesi Selatan berada di semenanjung barat daya Pulau Sulawesi dan diapit dengan Teluk Bone di sebelah timur dan Selat Makassar di sebelah barat. Karena posisi strategisnya yang terletak di tengahtengah Kepulauan Nusantara, keterlibatan Sulawesi Selatan dalam pelayaran dan perdagangan sudah berlangsung sejak lama. Daerah ini didiami oleh empat suku yang berbeda, yakni Makassar, Bugis, Mandar, dan Toraja.

Tidak seperti Jawa, kontrol politik atas seluruh wilayah Sulawesi Selatan baru diwujudkan sepenuhnya oleh pemerintah kolonial Belanda bersamaan dengan politik pasifikasi yang disertai ekspedisi militer pada Juni 1905. Sementara itu, pada 1906 pemerintah kolonial menata jazirah Sulawesi bagian selatan dan Sulawesi bagian tenggara ke dalam satu daerah pemerintahan administratif yang dikenal dengan Gouvernement Celebes en Onderhoorigheden. Penataan ini membentuk tujuh bagian pemerintahan (afdeeling), yaitu Makassar, Parepare, Bone, Bantaeng, Mandar, Luwu, dan Buton dan Pesisir Timur Sulawesi. Dalam perkembangannya, penataan ulang sistem pemerintahan di daerah luar Jawa pada 1938 kemudian mengubah penamaan daerah ini menjadi Residentie Celebes en Onderhoorigheden (Poelinggomang 2004; Poelinggomang et al. 2005).

Kondisi geografis menjadi landasan utama bagi aspek pertanian di Sulawesi Selatan. Selain keadaan 
tanahnya yang relatif subur, daratan Sulawesi Selatan juga ditandai dengan adanya jajaran pegunungan yang terbentang dari selatan ke utara dan sedikit cekungan di bagian tengah. Karena jajaran pegunungan itu, daerah ini seolah-olah terbagi ke dalam dua bagian, yakni daerah pesisir timur dan daerah pesisir barat.

Perbedaan curah hujan di kedua daerah tersebut memengaruhi masa panen padi. Daerah pantai timur biasanya memasuki masa panen padi pada Juni dan Juli, sedangkan daerah pantai barat, baru memasuki masa panen pada Oktober dan November (Anon 1934a:1). Tidak mengherankan apabila budi daya padi di Sulawesi Selatan berlangsung bergantian sepanjang tahun. Bahkan, hasil panennya dapat saling menutupi kekurangan antara satu daerah dan daerah yang lain (Pelras 2006).

Jazirah Sulawesi Selatan juga ditopang dengan adanya dua danau (Danau Tempe dan Sidenreng). Kedua danau ini terletak di bagian tengah Sulawesi Selatan. Di samping itu, terdapat pula sungai-sungai yang berukuran besar dan kecil. Aliran sungai-sungai itu sudah tentu sangat potensial untuk dijadikan sebagai sumber pengairan di sawah. Adapun beberapa sungai yang dimanfaatkan sebagai sumber pengairan penting selama periode kolonial Belanda, yakni Sungai Saddang, Rappang, Walanae, Bila, Cenrana, dan Jeneberang.

Keadaan lingkungan tersebut bukan hanya mendukung kegiatan budi daya padi, melainkan juga memengaruhi diversifikasi produk pertanian. Sebagai contoh, Danau
Tempe akan mengalami penyusutan di setiap musim kemarau. Karena itu, selalu tersedia lahan subur di daerah sekelilingnya akibat penyusutan tersebut, sekitar 150.000 bau $^{1}$. Lahan ini bersama dengan areal penanaman yang terdapat di sepanjang aliran Sungai Cenrana digunakan oleh masyarakat di Wajo dan Soppeng sebagai tempat penanaman jagung. Di daerah tersebut, kegiatan penanaman jagung biasanya dilakukan pada September, Oktober, dan November. Pada tahun-tahun normal, hasil produksi jagung cukup melimpah. Lahan di sekeliling Danau Tempe, misalnya, menghasilkan jagung yang mencapai 20.000 ton. Selain sebagai makanan sehari-hari yang melengkapi beras, jagung juga diekspor ke luar Hindia Belanda (Eropa) melalui pelabuhan Makassar. Adapun pintu keluar produk ini dilakukan di pelabuhan Palima (Teluk Bone) untuk selanjutnya dikapalkan ke Makassar. Tidak heran, komoditas jagung cukup menentukan perkembangan pesat Palima selama 1920-an (Ahmad dan Kila 2016; Anon 1924:1; Saraber 1929; Vuuren 1922:65). Selain itu, sejak akhir abad ke-19 kopra sudah menjadi produk ekspor penting Sulawesi Selatan. Produk ini terutama banyak dihasilkan di Selayar dan daerah pesisir Mandar. Produk pertanian lainnya adalah kopi, kemiri, kapuk, pinang, tembakau, dan kacang (Asba 2003; Laag 1941).

Dengan keadaan geografis di atas, pertanian menjadi mata pencaharian utama yang banyak melibatkan masyarakat di Sulawesi

\footnotetext{
11 bau sama dengan 0,71 hektar.
} 
Handep Jurnal Sejarah dan Budaya Vol. 4, No. 2, Juni 2021, hlm. 113-140

Selatan, khususnya sepanjang paruh pertama abad ke-20. Selain itu, tidak sedikit pula masyarakat yang bergiat dalam bidang perdagangan, industri, peternakan, pengumpulan produk hutan, nelayan, dan perkapalan Meskipun terlihat beragam, namun berdasarkan sensus 1930 aspek pertanian menjadi kegiatan yang paling banyak melibatkan masyarakat di Sulawesi Selatan, yakni sebesar 71,38\% dari jumlah orang yang bekerja saat itu (Harvey 1989).

Budi daya padi pada umumnya dilakukan di sawah dan ladang yang dapat dijumpai di berbagai daerah, seperti Afdeeling Bone, Afdeeling Parepare, Takalar, Gowa, dan Distrik Utara (Maros dan Pangkajene). Dengan jumlah yang lebih minim, sawah dan ladang juga dapat ditemukan di Afdeeling Luwu dan Afdeeling Mandar (Vorstman 1911). Hingga 1920-an, sawah-sawah di Sulawesi Selatan umumnya masih berupa sawah tadah hujan, sekalipun terdapat pula sawah beririgasi alamiah.

Hasil produksi padi sangat bergantung pada kondisi iklim dan curah hujan setiap tahunnya. Keadaaan gagal panen lumrah terjadi ketika musim kemarau berlangsung cukup lama. Hal ini tampak ketika pada 1919 terjadi kondisi kekeringan yang hebat, yang disebutkan telah melanda sawah di Afdeeling Bone. Pada tahun yang sama, kondisi kekeringan juga menyebabkan turunnya hasil panen padi di Bulukumba dan Sinjai (Anon 1919b:5). Terlambatnya penanaman padi karena curah hujan yang tidak menentu juga tidak jarang terjadi, seperti halnya yang tampak di daerah pantai timur
Sulawesi Selatan pada 1928 (ANRI 1929). Kemarau berkepanjangan yang membuat gagal panen sebenarnya masih terlihat hingga 1930-an. Sebagai contoh, kasus penurunan yang signifikan terhadap hasil panen padi di beberapa tempat pada 1930. Di Afdeeling Makassar dan Afdeeling Bone, kemarau yang berkepanjangan disebut telah menyebabkan kegagalan panen padi yang mencapai $60 \%$ dari total penanaman padi. Kasus serupa juga tampak di Onderafdeeling Jeneponto pada tahun yang sama, yang mengakibatkan padi mengalami kerusakan sebesar 70\% (ANRI 1931).

Selain faktor alamiah, hambatan produksi padi di Sulawesi Selatan juga berasal dari penyakit dan hama. Salah satu sumber menyebutkan bahwa walang sangit telah merusak tanaman padi di beberapa tempat pada 1910 . Selain itu, wabah tikus tidak jarang pula membuat kondisi gagal panen, sebagaimana tampak di sebagian wilayah Sidenreng dan Pinrang pada 1919. Laporan kolonial yang terbit pada 1923 menyebutkan bahwa beberapa tempat di Sulawesi Selatan hampir mengalami kegagalan panen karena adanya wabah serangga (Anon 1919a:1; ANRI 1911, 1923). Pada dasarnya, berbagai gangguan terhadap padi, seperti omo mentek, omo putih, wabah tikus, dan walang sangit tetap saja selalu muncul. Namun demikian, sampai 1941, berbagai hambatan itu hanya berpengaruh secara lokal dan tidak berpengaruh besar terhadap hasil panen secara keseluruhan di Sulawesi Selatan (Laag 1941).

Di samping kondisi geografis, sarana irigasi merupakan faktor penting 
lainnya dalam pertanian. Pada 1910-an, sawah irigasi teknis masih cukup terbatas. Situasi ini menyebabkan kegagalan panen masih membayangi penanaman padi. Pascapolitik pasifikasi, usaha awal dalam mengembangkan irigasi teknis yang dilakukan pemerintah kolonial baru terlihat pada awal 1910-an. Kondisi ini terutama bersamaan dengan usaha pemerintah kolonial untuk mengembangkan bidang pertanian di seluruh Hindia Belanda pada 1911 (Prince 2000). Saat itu, bentuk perhatian awal pemerintah tampak melalui penunjukan J.A.M. Van Buuren, salah seorang insinyur, guna mengadakan penyelidikan lokal terkait sistem pengairan di Sulawesi. Buuren menyelidiki secara langsung kondisi sarana pengairan di seluruh wilayah pemerintahan Celebes en Onderhoorigeheden antara 5 September 1911 hingga 15 September 1912 (Buuren 1911:2-7)

Hasil penyelidikan Buuren segera terbukti dengan mulai dibangunnya irigasi teknis di Afdeeling Bone pada 1912. Pembangungan irigasi awal ini diperkirakan dapat mengairi sawah sebanyak 47.300 bau. Adapun anggaran untuk pembangunan irigasi itu ialah sebesar $f 80.000$. Sejak 1919, pembangunan irigasi Pattiro (Bone) juga mulai dilakukan. Dalam pembangunan irigasi ini, sebanyak 13.000 bau sawah diperkirakan akan diairi secara teknis dengan mengandalkan Sungai Patiro. Sampai 1920-an, pembangunan irigasi berskala menengah di Bone juga dilakukan, seperti di Parigi, Alinge, Lakekallo, Lamade, dan Palengorang. Selain pembangunan irigasi baru, upaya pengembangan irigasi diwujudkan dalam bentuk perbaikan irigasi yang telah ada sebelumnya. Hal ini tampak dari perbaikan irigasi di Malakaji sejak 1915. Di bawah pengawasan J.C.A. Gundessen, upaya perbaikan juga dilakukan untuk irigasi Bantimurung selama 1910-an. Perbaikan irigasi ini diperkirakan akan mampu mengairi sawah sebanyak 11.000 bau (Heyting 1915; Vorstman 1911, 1924). Dengan berbagai upaya pengembangan irigasi tersebut, tidak mengherankan apabila Afdeeling Bone, Gowa, dan Maros terkenal sebagai penghasil padi utama di Sulawesi Selatan, khususnya hingga 1920-an. Onderafdeeling Soppeng (bagian dari Afdeeling Bone), misalnya, rata-rata produktivitas lahannya ialah sebanyak 47 pikul $^{2}$ padi basah untuk setiap satu hektar pada 1925. Angka itu merupakan hasil panen padi yang paling baik di Sulawesi Selatan (ANRI 1926).

Upaya pengembangan irigasi turut digiatkan di wilayah lain. Salah satunya di Afdeeling Parepare. Dalam sumber disebutkan bahwa pada 1914, sebuah proyek irigasi baru akan dikembangkan di Onderafdeeling Parepare. Proyek irigasi ini diperkirakan dapat mengairi sekitar 6.000 bau sawah (Vorstman 1924). Sayangnya, selama 1910-an pembangunan irigasi baru di Parepare tidak begitu gencar dibandingkan wilayah lain. Salah satu kendala utama saat itu ialah minimnya kas daerah. Padahal beberapa sungai yang penting di afdeeling ini cukup potensial untuk dimanfaatkan sebagai sumber pengairan di sawah. Sungai-sungai itu

\footnotetext{
${ }^{2} 1$ pikul sama dengan 61,76 kilogram.
} 
Handep Jurnal Sejarah dan Budaya Vol. 4, No. 2, Juni 2021, hlm. 113-140

ialah Sungai Sadang, Klempang, dan Bila. Berbeda dengan wilayah lain, pembangunan irigasi yang masif di Afdeeling Parepare baru mulai tampak pada 1920-an sampai 1930-an.Terlepas dari berbagai upaya pengembangan irigasi tersebut, hingga 1941, jumlah sawah yang berhasil diairi, baik sawah irigasi teknis maupun sawah irigasi nonteknis, baru mencapai 30\% dari total keseluruhan sawah di Sulawesi Selatan (391.446 ha) (Laag 1941).

Hal yang menarik ialah berbagai upaya pengembangan irigasi yang digalakkan pemerintah kolonial sejak 1910-an mulai membawa angin perubahan. Bentuk perubahan ini tampak dari area utama penghasil beras di Sulawesi Selatan selama 1930-an. Pada dekade ini, produksi beras kebanyakan bersumber dari Afdeeling Parepare (Sidenreng, Rappang, dan Pinrang), Onderafdeeling Wajo, dan Onderafdeeling Soppeng. Area itulah yang sebetulnya merupakan lumbung padi sekaligus penghasil utama beras ekspor di Sulawesi Selatan, terutama sepanjang 1930-an (Swaab 1936). Sebagai contoh, meskipun beberapa tempat mengalami gagal panen pada 1933, namun hasil panen padi di Sulawesi Selatan dianggap tetap berhasil dan menguntungkan. Hal ini terutama karena hasil panen padi yang memuaskan di Onderafdeeling Soppeng, Onderafdeeling Wajo, dan Afdeeling Parepare. Bagi daerahdaerah ini, sematan sebagai lumbung beras sebetulnya tidaklah berlebihan.

Selain faktor pengembangan irigasi, faktor jenis tanah juga perlu dipertimbangkan. Di Afdeeling Parepare, misalnya, pada umumnya tanah yang menjadi lahan penanaman padi ialah tanah regosol, grumosol, dan aluvial. Berbagai jenis tanah itu sangat sesuai untuk budi daya pertanian (Mulya 2017).

Di samping faktor pengembangan irigasi dan jenis tanah, perubahan area produksi beras selama 1930-an mudah dipahami dari luasnya areal persawahan di daerah-daerah tersebut. Berdasarkan perhitungan pajak tanah, pada 1936 , jumlah sawah di Onderafdeeling Soppeng, Onderafdeeling Wajo, dan Afdeeling Parepare yakni sebanyak 116.680 ha. Itu artinya bahwa sebesar $36 \%$ dari total keseluruhan sawah di Sulawesi Selatan berada di daerahdaerah tersebut (Anon 1934b:11; Swaab 1936).

Sejak 1924, Sulawesi Selatan telah dikategorikan sebagai "daerah surplus beras" 3 dengan jumlah 12.382 ton. Sebetulnya, pada 1923, daerah ini masih tergolong sebagai "daerah impor beras"4, yakni sebanyak 2.376 ton. Sementara itu, selama 1920-an, harga beras di pasaran terbilang relatif tinggi. Sebagai contoh, pada 1925 beras yang diolah sendiri dijual dengan kisaran harga $f 8-f 10,50$ per pikul. Sedangkan beras hasil olahan pabrik penggilingan padi ialah berkisar $f 10-f 12,50$ per pikul (ANRI 1924, 1925).

Meskipun status daerah surplus ekspor beras telah tercapai sejak 1920-an, namun hasil dari program intensifikasi pertanian di Sulawesi

${ }^{3}$ Daerah surplus ekspor beras ialah daerah yang memiliki jumlah ekspor lebih banyak dibandingkan jumlah impor beras.

${ }^{4}$ Daerah surplus impor beras adalah daerah yang memiliki jumlah impor beras lebih banyak dibandingkan jumlah ekspor beras. 
Selatan baru tampak jelas pada 1930an. Sebagai gambaran, pada 1930 telah terdapat sebanyak 15.300 ton surplus beras yang tersedia, walaupun setahun berikutnya mengalami penurunan menjadi 2.800 ton akibat kegagalan panen (Caron 1933:265). Sampai 1940, surplus beras setiap tahunnya tetap memperlihatkan adanya peningkatan, kecuali penurunan yang terjadi pada 1935 dan 1940 akibat kegagalan panen di beberapa tempat. Antara 1931 hingga 1940, rata-rata surplus ekspor beras yang dihasilkan setiap tahun ialah sebanyak 37.290 ton. Gambaran detailnya dapat disimak dari tabel berikut ini:

\begin{tabular}{|c|c|c|c|}
\hline Tahun & $\begin{array}{c}\text { Surplus } \\
\text { ekspor }\end{array}$ & Tahun & $\begin{array}{c}\text { Surplus } \\
\text { ekspor }\end{array}$ \\
\hline 1931 & 2.800 & 1936 & 35.900 \\
\hline 1932 & 16.500 & 1937 & 42.100 \\
\hline 1933 & 28.400 & 1938 & 60.000 \\
\hline 1934 & 41.200 & 1939 & 71.000 \\
\hline 1935 & 35.000 & 1940 & 40.000 \\
\hline
\end{tabular}

Tabel 1. Surplus ekspor beras di Sulawesi Selatan selama 1930-an (dalam ton). Sumber: Anon 1941:37; ANRI 1938:62; Caron 1933:265.

Satu hal yang menarik ialah kondisi panen yang berlangsung relatif stabil selama 1930-an. Modal inilah yang membuat Sulawesi Selatan tampil sebagai lumbung beras utama di kawasan Groote Oost (Timur Besar) bahkan di daerah luar Jawa. Sepanjang 1930-an, daerah-daerah di Groote Oost yang secara konsisten menghasilkan surplus beras ialah Bali, Lombok, dan Sulawesi Selatan. Selebihnya tergolong sebagai daerah surplus impor beras, kecuali Sunda Kecil yang sejak 1934 mulai dikategorikan sebagai daerah surplus ekspor. Pada tahun itu,
Sunda Kecil tercatat telah memiliki surplus beras sebanyak 600 ton (ANRI 1938:62).

Dengan gambaran tersebut, perbandingan produksi beras antara Sulawesi Selatan dengan Bali dan Lombok perlu dikemukakan lebih lanjut guna menentukan daerah yang menjadi lumbung beras di Groote Oost. Pada 1932, suplus beras Bali dan Lombok sebetulnya masih lebih tinggi, yakni 21.200 ton, dibandingkan Sulawesi Selatan yang hanya menghasilkan sebanyak 16.500 ton. Namun demikian, setahun berikutnya Sulawesi Selatan justru tercatat telah mengungguli Bali dan Lombok dalam jumlah surplus ekspor beras. Keadaan ini terus bertahan pada tahun-tahun berikutnya. Pada 1937, misalnya, Sulawesi Selatan menghasilkan surplus beras sebanyak 42.100 ton. Adapun Bali dan Lombok menghasilkan surplus ekspor sebanyak 26.900 ton atau $63 \%$ dari jumlah yang dihasilkan Sulawesi Selatan pada tahun yang sama (ANRI 1938:62). Dengan demikian, keadaan tersebut jelas menunjukkan bahwa Sulawesi Selatan pada dasarnya telah berkedudukan sebagai lumbung beras utama di Groote Oost.

Selain Bali, Lombok, dan Sulawesi Selatan, terdapat pula beberapa daerah di luar Jawa yang termasuk daerah surplus beras pada 1930-an. Di antaranya ialah Tapanuli, Lampung, Bengkulu, dan Sunda Kecil (Touwen 2001:252). Meskipun demikian, jumlah ekspor beras di daerah-daerah itu masih terbilang minim dibandingkan jumlah ekspor beras di Bali, Lombok, dan Sulawesi Selatan. 
Terlepas dari perkembangan pertanian padi yang positif selama 1930-an, kedudukan Sulawesi Selatan sebagai lumbung beras utama di Timur Besar sebenarnya hanya sebuah bentuk kontinuitas dalam proses sejarah. Jauh sebelum itu, beras sudah lazim diperdagangkan dalam kegiatan pelayaran dan perdagangan di Sulawesi Selatan. Pada 1512 hingga 1515, misalnya, Tome Pires telah menjumpai orang Makassar yang berdagang hingga ke Malaka, Jawa, Siam, dan kota-kota pelabuhan yang berada di antara Pahang dan Siam. Dalam pelayarannya, mereka biasanya memuat beras putih, emas, bretangi (kain katun merah), dan tekstil dari Bengal (Cortesao 2015:312-13).

Sejalan dengan kesaksian Tome Pires, Reid (2004) beranggapan bahwa upaya budi daya padi secara besarbesaran di Sulawesi Selatan baru tampak pada abad ke-16. Dalam konteks sejarah masyarakat Sulawesi Selatan, arti penting padi sebetulnya sudah tampak sebelum abad ke-16. Studi Macknight, misalnya, mengulas soal basis ekonomi negara-negara awal (early states) di Sulawesi Selatan. Menurutnya, sebelum abad ke-16 kekuasaan politik negara awal yang berkecimpung dalam dunia perdagangan maritim, terutama bersumber dari kontrol pertanian dan keterlibatan mereka di dalamnya (Macknight 1983). Sementara itu, dengan mengkaji oriza phytolith (mikrofosil biogenik berbahan silika pada padi) di situs Allangkanangnge (Wajo) yang cocok untuk pertanian ladang, Bulbeck dan Caldwell (2008) tiba pada kesimpulan bahwa asal mula kerajaan-kerajaan di Sulawesi Selatan pada abad ke-13 berkaitan erat dengan upaya intensifikasi pertanian padi, sebagai bentuk tanggapan atas ketersediaan barang perdagangan, terutama tekstil dari India dan barang-barang keramik dari Cina dan Asia Tenggara. Dengan kondisi itu, tidak heran pula jika pada 1540 -an beras telah menjadi komoditas ekspor utama di Sulawesi Selatan, di samping budak (Reid 2004).

Situasi itu tidak terlepas dari dukungan daerah pedalaman Makassar. Daerah yang dimaksud ialah Maros dan Takalar. Kedua daerah subur ini terkenal sebagai lumbung padi untuk perdagangan Makassar. Pada masa itu, Makassar berkembang sebagai pangkalan bagi para pedagang, terutama pedagang Melayu, untuk memperoleh beras yang kemudian dipertukarkan dengan pala, bunga pala, dan cengkeh di Maluku. Bahkan, tampilnya Makassar sebagai basis perdagangan rempah-rempah pada awal abad ke-17 tidak terlepas dari usaha produksi beras secara besarbesaran, di samping jaminan keamanan dari penguasa Gowa-Tallo (Reid 2004). Hingga akhir abad ke-19, dalam kegiatan pelayaran dan perdagangan di Sulawesi Selatan, komoditas beras tetap berkedudukan sebagai salah satu barang niaga penting (Poelinggomang 2016).

Adanya kontinuitas tersebut sudah barang tentu bertalian dengan faktor lingkungan. Artinya, kondisi tanah yang sebagian besar relatif cocok untuk penanaman padi bukan hanya sekadar menjadikan praktik budi daya padi memiliki kaitan yang erat dengan sejarah masyarakat Sulawesi Selatan. 
Namun, kesuburan tanah juga telah menjadi "panggung" yang seolah-olah hanya menanti momentum, yakni munculnya upaya-upaya yang lebih serius untuk mengembangkan potensi pertanian di Sulawesi Selatan.

Itulah sebabnya, dalam memori serah terima jabatannya yang ditulis pada 1924, F.C. Vorstman sangat menyarankan kepada penerusnya agar upaya pengembangan irigasi yang lebih intensif di Sulawesi Selatan dapat diwujudkan, terutama di Afdeeling Bone dan Afdeeling Parepare. Dengan pengembangan itu, menurutnya, seluruh bagian timur Kepulauan Nusantara kelak akan bergantung dari Sulawesi Selatan untuk kebutuhan berasnya (Vorstman 1924:78). Pada akhirnya, keyakinan Vorstman itu terbukti pada enam tahun berikutnya, sebagaimana tampak dari hasil produksi beras di Sulawesi Selatan sepanjang 1930-an. Demikianlah faktor-faktor yang kiranya telah memungkinkan Sulawesi Selatan berkembang sebagai daerah surplus beras, sekalipun hal itu bersamaan dengan situasi ekonomi yang tidak kondusif akibat depresi ekonomi global 1930-an.

\section{Perdagangan Beras: Berkah di Balik Kontrol Negara}

Bermula dari krisis di Wall Street, depresi ekonomi global 1930-an kemudian mengubah pandangan pemerintah kolonial terkait masalah perberasan di Hindia Belanda. Hal ini berawal ketika krisis ekonomi yang mengguncang perekonomian dunia disertai dengan hasil panen padi yang cukup melimpah di daratan Asia
Tenggara. Bersamaan dengan itu, negara-negara pengimpor beras juga mulai menerapkan pembatasan impor beras asing. Konsekuensinya, ketika itu harga beras di pasar internasional jatuh mendahului harga produk ekspor Hindia Belanda.

Karena perdagangan beras masih berada di bawah pasar bebas (free trade), kondisi krusial itu sudah barang tentu dapat menjadi ancaman bagi petani pribumi yang menghasilkan surplus beras domestik. Selain itu, jatuhnya harga beras juga dianggap akan mengancam kemampuan penduduk pribumi, terutama petani, dalam hal pembayaran pajak. Pada akhirnya, negara lebih memilih untuk melindungi pasar domestik pertanian. Keputusan ini terutama menyangkut kepentingan daerah-daerah surplus beras, seperti Jawa, Sulawesi Selatan, dan Lombok (Touwen 2001; Eng 1996, 2000). Hal itu tampak jelas ketika pada 1931 pemerintah kolonial mulai meninggalkan kebijakan laissez-faire tradisional (Furnivall 2009).

Keputusan tersebut segera disertai dengan disahkannya sebuah regulasi yang menandai keterlibatan negara dalam hal perdagangan pada 1933 . Regulasi ini disebut dengan Rijstinvoer Ordonantie. Regulasi ini bertujuan untuk mengurangi ketergantungan terhadap beras impor dari luar Hindia Belanda. Regulasi itu juga dimaksudkan untuk menstabilkan harga beras domestik. Melalui regulasi tersebut, keinginan pembatasan impor beras diwujudkan dengan mengadakan sebuah perizinan khusus. Perizinan khusus dalam hal impor beras asing ini hanya dikeluarkan oleh Direktur 
Handep Jurnal Sejarah dan Budaya Vol. 4, No. 2, Juni 2021, hlm. 113-140

Pertanian, Perindustrian, dan Perdagangan. Hal yang menarik ialah aturan pembatasan impor beras juga mengharuskan pencantuman nama pelabuhan di dalam lisensi, di samping memuat besaran pajak (Anon 1933f). Dengan pemberlakuan regulasi tersebut, bisa disimpulkan bahwa kegiatan perniagaan beras di Hindia Belanda bukan lagi berada di bawah pasar bebas. Dalam kondisi itulah, depresi ekonomi 1930-an merupakan momentum bagi Sulawesi Selatan untuk berperan sebagai salah satu lumbung beras.

Komoditas beras di Sulawesi Selatan bukan hanya diperdagangkan dalam daerah (intraregional), melainkan juga antardaerah (interregional). Selain itu, beras biasanya diperjualbelikan di pasar yang terdapat di daerah-daerah pedalaman ataupun pusat perdagangan di daerah pesisir, seperti Makassar dan Parepare. Dari daerah produksi, beras diangkut melalui jalur darat dan jalur sungai. Kuda beban ( $k u d a$ pa'teke) menjadi moda transportasi utama di darat. Khususnya di pantai timur Sulawesi Selatan, Sungai Cenrana merupakan saluran utama dalam hal penyaluran komoditas beras, terutama beras yang dihasilkan dari Bone, Wajo, dan Soppeng. Perahu layar milik pribumi menjadi tumpuan utama pengangkutan beras di sungai tersebut. Di muara sungai Cenrana, komoditas beras kemudian dimuat di pelabuhan Palima. Sejak paruh kedua 1920-an, pengangkutan komoditas beras mulai mengandalkan mobil truk (vrachtauto). Hal ini terutama sejalan dengan upaya pengembangan jaringan jalan raya yang semakin intensif ketika itu. Sementara itu, dalam konteks perniagaan maritim, pelabuhan Makassar (tanda panah hijau di gambar 1), Parepare (tanda panah biru di gambar 1), dan Palima (tanda panah merah di gambar 1) adalah pintu-pintu keluar penting untuk komoditas beras yang hendak dikapalkan menuju daerah seberang.

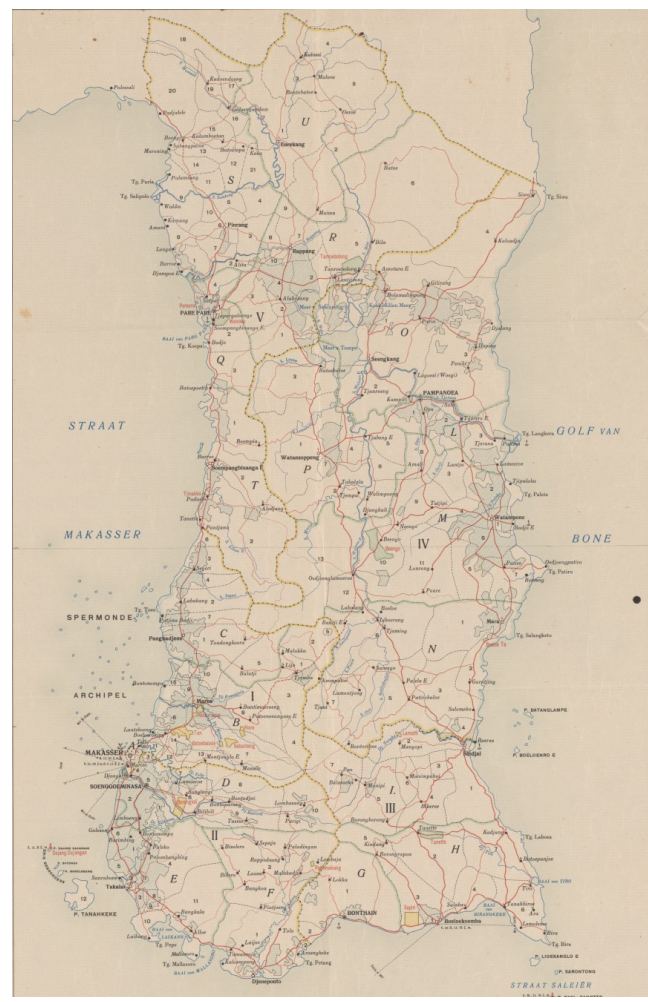

Gambar 1. Peta Sulawesi Selatan yang menunjukkan letak pelabuhan-pelabuhan ekspor beras (1920). Sumber: diolah dari https:/digitalcollections.universiteitleiden.nl/ view/item $/ 815176$ ?solr nav $\% 5 \mathrm{Bid} \% 5 \mathrm{D}=0$ ec63c5ce9c4208fb782\&solr nav $\% 5$ Bpage $\% 5 \mathrm{D}=0 \&$ solr nav $\% 5$ Boffset $\% 5 \mathrm{D}=17$.

Sampai 1920-an, perniagaan komoditas beras di Sulawesi Selatan belum menunjukkan adanya perkembangan signifikan. Dengan kata lain, perdagangan beras masih berlangsung secara tradisional dan jumlah beras yang diekspor pun relatif terbatas, 
terutama ke Maluku, Manado, daerah pesisir Kalimantan, dan Sunda Kecil (Anon 1931; Touwen 2001). Selain itu, antara 1910 sampai 1913, pelabuhan Makassar juga sempat mengekspor beras ke luar Hindia Belanda, seperti ke Papua Nugini, Australian, dan Timor Dili (Nur 2017:248). Terkait hal ini, kedudukan pelabuhan Makassar yang berperan sebagai pelabuhan transit bagi kawasan Indonesia bagian timur perlu pula dipertimbangkan. Komoditas beras yang diekspor sudah barang tentu bukan sepenuhnya hasil produksi beras dari Sulawesi Selatan. Hal ini tampak jelas dalam perdagangan impor di pelabuhan Makassar, di mana beras impor masih tercatat sebagai barang impor yang penting. Pada September 1918, misalnya, beras yang diimpor dari Siam, Rangoon, dan Saigon tercatat sebanyak 881 pikul. Pada saat yang sama, beras juga didatangkan dari Lombok dengan jumlah 473 pikul (Anon 1919b:5).

Selain faktor produksi padi yang minim, terdapat dua hal lain yang menyebabkan terhambatnya perkembangan perniagaan beras. Pertama, kebijakan pasar bebas yang notabene masih berlangsung di Hindia Belanda. Situasi ini menyebabkan kebutuhan beras di Hindia Belanda, terutama daerah luar Jawa, cenderung bergantung dari suntikan beras impor asing dengan harga yang relatif lebih murah. Beras impor terutama dikapalkan melalui Singapura yang diangkut langsung melalui kapal uap milik Koninklijke Paketvaart Maatschappij (selanjutnya disebut KPM) menuju daerah tujuan. Selain itu, persaingan dengan perusahaan pelayaran Cina di sebelah barat Kepulauan Nusantara telah mendorong pihak KPM untuk menurunkan biaya pengangkutan (Dick 1990:7-8). Akibatnya, biaya pengangkutan tentunya semakin murah. "Makassar tidak dapat diandalkan sebagai pelabuhan beras di masa mendatang," demikian komentar dalam salah satu sumber yang memaparkan kondisi perdagangan ekspor di pelabuhan Makassar pada awal 1920an (Broersma 1925).

Kedua ialah kualitas beras. Beras Sulawesi Selatan sering kali dikatakan mempunyai kualitas lebih rendah dibandingkan beras impor. Ketika Rijstinvoer Ordonantie mulai diberlakukan pada 1933, kedua kenyataan itulah yang dihadapi pemerintah kolonial Belanda di Batavia.

Tindakan awal negara ialah menetapkan daerah-daerah di Hindia Belanda yang tergolong sebagai daerah defisit beras dan daerah surplus beras. Maluku, Sulawesi Utara, Kalimantan Timur, dan Kalimantan Selatan adalah daerah-daerah yang tergolong sebagai daerah defisit beras saat itu. Daerah inilah yang ditentukan sebagai daerah pembuangan surplus beras untuk Sulawesi Selatan (Moeljono 1971). Langkah ini disertai upaya untuk mengadakan pertemuan secara langsung dengan pejabat pemerintah kolonial setempat. Upaya ini tampak saat A. Luytjens, Kepala Bagian Ekonomi Pertanian, melawat ke Makassar pada 27 Juli 1933. Dalam lawatan ini, Luytjens ditugasi untuk mengadakan konferensi dengan Celebes en Onderhoorigeheden, yang saat itu dijabat L.J.J. Caron 
Handep Jurnal Sejarah dan Budaya Vol. 4, No. 2, Juni 2021, hlm. 113-140

(memerintah 1929-1933). Pembahasan utama dalam konferensi itu ialah persoalan aturan pembatasan impor beras. Selain mengadakan konferensi, Lutyjens juga bermaksud untuk meninjau secara langsung kondisi perberasan di Sulawesi Selatan (Anon 1933g:1).

Tugas utama selanjutnya ialah memperbaiki kualitas beras. Hal ini penting karena berhubungan dengan persoalan selera penduduk di Sulawesi Utara. Perlu diketahui, Manado sudah sejak lama mengimpor beras dari luar Hindia Belanda, terutama Saigon, guna memenuhi kebutuhan beras untuk masyarakat setempat. Sementara itu, hal mendasar yang membuat kualitas beras Sulawesi Selatan menjadi rendah ialah kurang maksimalnya proses pengolahan padi di pabrik penggilingan. Keadaan itulah yang setidaknya telah mendorong pemerintah untuk terlibat langsung dalam meningkatkan kualitas beras. Hal ini tampak jelas ketika Ir. Tan Sin Houw, salah seorang konsultan industri di Departemen Pertanian, diberi tugas untuk meninjau langsung kondisi pabrik penggilingan padi di Makassar dan Parepare pada 9 Agustus 1933. Selain itu, ia juga bermaksud untuk memberi penerangan kepada para pemilik pabrik penggilingan di kedua daerah itu. Pada akhir 1933, selama tiga bulan lamanya konsultan itu telah tinggal di Makassar dan Parepare. Tujuannya ialah agar upaya pemberian informasi teknis dan pendampingan dapat berlangsung dengan lancar. Pada 1935, konsultan itu sekali lagi mengunjungi Sulawesi Selatan. Saat itu, ia bermaksud untuk mengawasi penerapan saran-saran yang bersifat teknis di masa penugasan sebelumnya (Anon 1933h:1, 1933e:2, 1933d:1, 1935b:1).

Rendahnya kualitas beras ekspor juga bersumber dari beras tumbuk. ${ }^{5}$ Karena proses penumbukan itu, beras yang dihasilkan memiliki tingkat patahan yang tinggi. Sebelum 1933, beras inilah yang lazim diolah dalam pabrik penggilingan padi dan menjadi beras ekspor asal Sulawesi Selatan. Oleh karena itu, untuk meningkatkan kualitas beras ekspor, pemerintah juga mulai melarang beras tumbuk untuk diolah di pabrik penggilingan, kecuali untuk konsumsi lokal (Mey 1935:39). Dengan demikian, pemilik pabrik penggilingan padi hanya diizinkan mengolah gabah dan beras ludah untuk dijadikan beras ekspor. Negara sekali lagi menerbitkan sebuah aturan menyangkut kualitas beras pada 1939. Aturan ini disebut Peraturan Gabah. Tujuannya ialah untuk memastikan setiap gabah yang akan diolah di pabrik penggilingan dalam kondisi yang betul-betul kering. Pada awalnya, regulasi ini diberlakukan di Afdeeling

\footnotetext{
Secara umum, proses pengolahan padi menempatkan beras Sulawesi Selatan ke dalam tiga kategori, yaitu: (1) beras ludah (bras loedah), yakni beras yang telah melalui proses penumbukan sebanyak satu kali; (2) beras tumbuk (bras toemboek), yakni beras yang telah melalui proses penumbukan sebanyak dua kali; (3) beras putih (witte rijst), yakni beras yang dihasilkan melalui pabrik penggilingan padi. Selain gabah, beras ludah dan beras tumbuk juga biasanya diolah melalui pabrik penggilingan padi. Hasilnya disebut dengan beras putih, yang lazim diperjualbelikan untuk perdagangan beras antardaerah di Sulawesi Selatan.
} 
Bone dan Parepare. Namun demikian, dalam perkembangannya, aturan itu diberlakukan pula di seluruh Sulawesi Selatan (Laag 1941).

Penetapan harga beras tentu tidak luput dari perhatian negara saat itu, kendati langkah ini telah tampak pada masa sebelumnya, khususnya selama Perang Dunia I. Sebelum menetapkan harga beras, Gubernur Celebes en Onderhoorigeheden akan berkonsultasi terlebih dahulu kepada Departemen Pertanian, Perindustrian, dan Perdagangan. Sebagai gambaran terkait penetapan harga beras, pada November 1933 harga pasaran yang ditetapkan untuk beras putih ialah $f 3,50$ per pikul. Selain beras putih, beras ludah juga tidak luput dari upaya penetapan harga tersebut. Jenis beras ini mulai ditentukan harga maksimumnya sejak 1934. Hal yang menarik ialah tindakan penetapan harga telah menguntungkan para petani. Sebuah sumber menyebutkan bahwa sebelum penetapan harga, petani sering kali dicurangi oleh para pemilik pabrik penggilingan padi yang memanipulasi harga beras (Anon 1933b:1, 1934b:11).

Berikutnya ialah persoalan pengemasan komoditas beras. Sebelum keterlibatan negara, komoditas beras di Sulawesi Selatan biasanya dikemas dengan menggunakan karung yang dibuat dari daun nanas. Dalam istilah setempat, kemasan ini dikenal dengan balasse. Dalam kasus Parepare, beras yang dikemas dengan balasse dimuat oleh perahu layar untuk dikapalkan ke daerah-daerah seberang, terutama ketika angin muson timur berhembus. Sejak 1933, pemerintah kolonial Belanda kemudian mengenalkan bentuk pengemasan baru yang disebut dubbelzak (karung ganda atau karung goni). Tidak seperti beras dalam kemasan balasse yang dikapalkan langsung ke daerah seberang setelah pelaut memperoleh beras dari para pemilik pabrik penggilingan, beras dalam kemasan karung goni umumnya ditaruh terlebih dahulu di gudanggudang pelabuhan atau sekitar pelabuhan. Selanjutnya, beras kemasan karung goni akan diangkut menggunakan kapal-kapal milik KPM (Anon 1933c:1; Nur 2003; Schimmel 1937).

Kontrol negara juga menyentuh persoalan pengangkutan beras. Pada 1934, melalui prakarsa Departemen Urusan Ekonomi, premi transportasi bagi kapal KPM mulai diberlakukan untuk pelabuhan-pelabuhan di Sulawesi Selatan. Sebagai contoh, jumlah premi transportasi untuk muatan beras yang ditetapkan ialah f0,50 per $100 \mathrm{~kg}$ pada 1935 (Anon 1935a; Swaab 1936). Hal yang menarik ialah perusahaan KPM juga memindahkan jadwal keberangkatan kapal di pelabuhan Makassar, yakni dari hari Jumat pagi ke Kamis sore di jalur 19 dan 20. Pemindahan jadwal ini dilakukan agar kapal KPM dapat tiba di Parepare pada hari Jumat pagi. Pemindahan tersebut sudah tentu membuat aktivitas bongkar muat, terutama beras, di Parepare menjadi lebih lancar (Anon 1933a:1). Oleh sebab itu, dari berbagai macam bentuk keterlibatan negara, bisa disimpulkan bahwa hal tersebut sudah menyentuh perbaikan sistem perdagangan beras. 
Handep Jurnal Sejarah dan Budaya Vol. 4, No. 2, Juni 2021, hlm. 113-140

\begin{tabular}{|c|c|c|c|}
\hline Pelabuhan & 1932 & 1934 & 1938 \\
\hline Makassar & 4.730 & 10.000 & 12.967 \\
\hline Parepare & 12.323 & 37.000 & 52.334 \\
\hline Palima & 2.754 & 4.170 & 11.106 \\
\hline
\end{tabular}

Tabel 2. Ekspor beras Sulawesi Selatan di tiga pelabuhan utama (dalam ton).

Sumber: Anon 1935a, 1939; Caron 1933; Heringa 1933.

Selain sistem perdagangan, kontrol negara juga berpengaruh signifikan terhadap jumlah ekspor beras di Sulawesi Selatan, sebagaimana tercermin dari tabel 2 di atas. Pada 1932, misalnya, ekspor beras Sulawesi Selatan ialah 19.807 ton. Jumlah ini telah meningkat pada 1934, yakni sebanyak 51.170 ton. Empat tahun berikutnya, ekspor beras di Sulawesi Selatan tetap memperlihatkan peningkatan dengan jumlah 76.407 ton. Hal ini menunjukkan bahwa ekspor beras telah mengalami peningkatan sebanyak $386 \%$ dari jumlah beras yang diekspor melalui tiga pelabuhan (Parepare, Makassar, dan Palima) pada 1932.

Implikasi dari pembatasan impor beras asing pada 1933 ialah kebutuhan beras di Hindia Belanda akan banyak bergantung pada hasil produksi domestik, khususnya kebutuhan beras di daerah luar Jawa. Pada 1937, misalnya, Jawa telah mengekspor beras ke daerah luar Jawa dengan jumlah 197.143 ton, sementara Bali dan Lombok menyuntik beras ke daerah luar Jawa dengan jumlah 10.507 ton. Pada tahun yang sama, Sulawesi Selatan sendiri mengekspor beras ke daerah luar Jawa sebanyak 44.719 ton (Touwen 2001). Data ini jelas menunjukkan bahwa Sulawesi Selatan mengekspor beras ke daerah luar Jawa lebih banyak daripada Bali dan Lombok. Dengan demikian, fakta itu menegaskan kembali posisi Sulawesi Selatan yang berperan sebagai lumbung beras, baik di Groote Oost maupun di antara daerah luar Jawa.

Karena peran tersebut, menjelang akhir 1930-an, satu dari dua proyek pembangunan irigasi terbesar di daerah luar Jawa dibangun di Sulawesi Selatan, tepatnya di wilayah Rappang dengan memanfaatkan aliran Sungai Saddang (Eng 1996:58). Hal yang menarik ialah pendapat Pradadimara yang menyatakan bahwa depresi ekonomi 1930-an sesungguhnya tidak menimbulkan gangguan besar bagi masyarakat pedesaan di Sulawesi Selatan (2016:209), walaupun kopra dan kopi yang merupakan komoditas ekspor penting mengalami penurunan harga. Tidak menutup kemungkinan bahwa minimnya pengaruh krisis malaise ekonomi itu bertolak dari perkembangan perniagaan beras yang positif.

\section{Jaringan Perniagaan}

Jenis beras Sulawesi Selatan yang populer diperdagangkan saat itu ialah beras banda. Selain itu, aktivitas perniagaan beras di Sulawesi Selatan sudah tentu melibatkan berbagai aktor ekonomi di dalamnya. Secara umum, aktor produsennya adalah masyarakat pribumi, kendati beberapa orang Tionghoa juga disebut memiliki lahan persawahan, seperti Ang Goan Seng di daerah sekitar Makassar (Wirawan 2013:131). Adapun aktor pedagang perantara dan eksportirnya kebanyakan merupakan orang Tionghoa dan 
pribumi, terutama Bugis dan Makassar.

Berdasarkan laporan Residen Celebes en Onderhoorigheden, pada 1941 perniagaan beras di Sulawesi Selatan didominasi tiga perusahaan bermodal yang besar milik orang Tionghoa atau dikenal dengan Kongsi Tiga ( Laag 1941:18). Pada 1940, peran Sulawesi Selatan sebagai lumbung beras utama di Groote Oost ditopang dengan keberadaan 40 pabrik penggilingan padi di Sulawesi Selatan yang tersebar di berbagai tempat (Harvey 1989:64), baik milik orang Tionghoa maupun pribumi.

Keunggulan pedagang Tionghoa atas penguasaan kapital tidak selalu menunjukkan adanya dominasi atas munculnya inisiatif baru. Dalam kasus perdagangan beras di Parepare, pendirian sebuah pabrik penggilingan padi yang paling lengkap dan modern di Sulawesi Selatan justru diinisiasi dan dibiayai oleh pedagang Bugis Parepare. Pabrik yang beroperasi dengan nama Laoemma-Hamid ini berada di sekitar pelabuhan Parepare dan diresmikan pada 9 Juni 1939 (Musyaqqat dan Pradjoko 2020:121).

Terlepas dari hal itu, dalam konteks perniagaan maritim, komoditas beras pada dasarnya tidak hanya dibawa kapal KPM, tetapi juga perahu layar pribumi. Para pelaut Bugis dan Makassar menjadi agensi dalam hal pengangkutan komoditas beras ke daerah-daerah seberang. Di samping itu, para pelaut Mandar tentunya turut berperan penting. Dengan jaringan maritim yang berporos di pelabuhan "kembar" Pambauang dan Majene, para pelaut Mandar biasanya memuat beras yang dihasilkan di daerah pesisir
Sulawesi Selatan, seperti Pangkajene, Pinrang, Parepare, dan Barru, untuk kemudian dibawa ke Mandar maupun ke daerah seberang. Menurut Hamid (2019), pada abad ke-19 para pelaut Mandar telah intens mengapalkan beras, kelapa, minyak kelapa, sarung bugis, dan budak belian ke daerah pesisir Kalimantan Timur. Mereka biasanya membawa hasil hutan, terutama kayu, sebagai muatan kembali menuju pantai barat Sulawesi dengan memanfaatkan tiupan angin muson barat daya. Jika dibandingkan dengan kawasan laut lain, ramainya kegiatan pelayaran di Selat Makassar juga erat kaitannya dengan perniagaan beras pada 1930-an (Hamid 2019:103).

Jaringan perniagaan beras di Sulawesi Selatan meliputi Maluku, Sulawesi Utara, Kalimantan Timur, Kalimantan Selatan, Sunda Kecil, dan Jawa. Jaringan ini tidak lain merupakan kelanjutan dari aktivitas pelayaran dan perdagangan beras pada masa sebelumnya. Karena itu, penetapan pemerintah kolonial perihal daerah pembuangan surplus beras bagi Sulawesi Selatan pada 1933, sesungguhnya hanya mempertahankan kontinuitas aktivitas maritim masyarakat di Sulawesi Selatan.

Berkaitan dengan jaringan tersebut, hingga menjelang akhir 1920-an, aktivitas perniagaan beras sebenarnya masih terkonsentrasi di pelabuhan Makassar, yang berkedudukan sebagai pelabuhan transit untuk berbagai macam komoditas sekaligus pusat perniagaan komoditas kopra di kawasan Groote Oost (Asba 2003; Touwen 2001). Namun, pada 1930, sebuah laporan kolonial menyatakan 
Handep Jurnal Sejarah dan Budaya Vol. 4, No. 2, Juni 2021, hlm. 113-140

bahwa sebagian besar ekspor beras di Sulawesi Selatan justru telah beralih ke pelabuhan Parepare, yang juga berada di pantai barat Sulawesi Selatan. Sementara itu, perdagangan beras di Makassar telah menurun secara signifikan saat itu (Anon 1931:26).

Terkait arti penting Parepare sebagai pelabuhan beras utama di Sulawesi Selatan, Musyaqqat dan Pradjoko (2020) menuturkan bahwa selain potensi daerah hinterland, faktor kebijakan pemerintah kolonial berupa Rijstinvoer Ordonantie 1933 dan program intensifikasi pertanian di daerah pedalaman pelabuhan turut memainkan peranan penting. Berdasarkan tabel 2 yang terdapat di bagian sebelumnya, pada 1932 Parepare telah mengekspor sebanyak $62 \%$ dari total ekspor (19.807 ton) di tiga pelabuhan tersebut. Kondisi itu terus meningkat setiap tahun. Bahkan, besarnya mencapai $68 \%$ dari 76.407 ton beras yang diekspor dari tiga pelabuhan tersebut pada 1938 .

Perkembangan peran pelabuhan Parepare tersebut tampak sejalan dengan peningkatan jumlah hilir mudik perahu layar pada 1930-an. Sebagai gambaran, pada 1932 jumlah kunjungan perahu layar masih tercatat sebanyak 1.461 dengan total tonase $38.200 \mathrm{~m}^{3}$. Namun, pada 1939 kunjungan perahu telah meningkat signifikan, yakni sebanyak 2.196 perahu dengan total tonase $68.073 \mathrm{~m}^{3}$ (Musyaqqat dan Pradjoko 2020). Dengan pasokan beras yang melimpah dari daerah pedalaman dan akses yang lebih dekat ke Kalimantan dan Jawa, perniagaan beras di Parepare juga telah berhasil mengalihkan kegiatan pelayaran dan pengangkutan dari sebagian besar pelaut dan pedagang yang bermukim di pantai timur Sulawesi Selatan, terutama Bone (Ijzereef 1994:63-65). Bahkan, ramainya aktivitas perdagangan beras di Parepare selama 1930-an turut memengaruhi kondisi infrastruktur pelabuhan. Menjelang Perang Dunia II, dari sembilan dermaga yang tersedia, dua di antaranya merupakan dermaga pabrik penggilingan padi yang dikhususkan untuk memuat komoditas beras (Anon 1945:25). Berbagai kondisi tersebut jelas memperlihatkan bahwa perdagangan beras telah membawa pengaruh signifikan terhadap dinamika pelabuhan ekspor di Sulawesi Selatan, khususnya pelabuhan Parepare.

Sebenarnya terdapat perbedaan karakter antara pelabuhan Makassar dan pelabuhan Parepare dalam konteks perniagaan beras. Jika suplai beras Makassar didatangkan dari daerah pedalaman, pulau-pulau lain, dan daerah luar Hindia Belanda, Parepare justru sepenuhnya bergantung dengan hasil produksi pertanian dari daerah penyangganya. Daerah pedalaman pelabuhan Parepare ialah Parepare, Pinrang, Sidenreng, Rappang, Barru, Pangkajene, Wajo, dan Soppeng. Daerah-daerah itulah yang berperan, terutama dalam hal menyuplai beras ke Parepare. Terlepas dari peran dominan pelabuhan Parepare, ketiga pelabuhan pada dasarnya tetap memperlihatkan peningkatan jumlah beras yang diekspor selama 1930-an (lihat tabel 2). Kondisi tersebut sudah tentu terkait erat dengan aturan pembatasan impor beras yang diterapkan sejak 1933. 
Dalam konteks perniagaan beras dalam daerah, beberapa pelabuhan lainnya, seperti Wajo dan Majene, sebenarnya turut berkontribusi untuk kegiatan ekspor pada 1930-an. Pelabuhan Wajo, misalnya, mengekspor beras ke wilayah atau pulau-pulau sekitarnya, seperti Malili, Palopo, Kendari, Kolaka, Buton, Muna, dan Selayar. Pelabuhan-pelabuhan di Bone, termasuk Palima, juga berperan untuk kegiatan ekspor komoditas beras ke daerah-daerah itu (Beukering 1935:1264). Namun demikian, jumlah beras yang diekspor ke daerah yang telah disebutkan tersebut tidak terlalu signifikan. Oleh karena itu, perniagaan beras dalam daerah di Sulawesi Selatan bukan hanya berlangsung melalui darat, tetapi juga laut.

Sementara itu, dalam konteks perdagangan beras antardaerah, terdapat satu hal menarik mengenai jaringan perdagangan. Hal ini terutama berkaitan dengan aktivitas impor beras di Manado. Walaupun pembatasan impor beras asing secara resmi mulai diberlakukan di beberapa daerah sejak 1933, namun pada pertengahan 1934 Manado nyatanya masih mengimpor beras dari luar Hindia Belanda, yakni beras Saigon. Berdasarkan keterangan sumber, saat itu pemerintah kolonial di Manado membuka separuh dari kebutuhan beras lokal untuk beras impor Saigon, yang harganya lebih rendah dari beras Sulawesi Selatan (perbedaannya ialah 55 sen per pikul). Bahkan, selama Agustus dan September 1934, Manado kemudian terbuka sepenuhnya untuk impor beras asing (Anon 1935a). Adanya fakta ini pada dasarnya menyanggah pendapat
Prince (2000:239) yang menyatakan bahwa antara 1929 hingga 1936 hubungan pasar beras domestik dengan pasar beras internasional terputus sama sekali seiring kebijakan pemerintah kolonial dalam masalah beras. Dengan demikian, kesimpulan Prince tersebut perlu ditinjau kembali.

\section{SIMPULAN}

Perdagangan beras di Hindia Belanda sesungguhnya memperlihatkan dinamika yang kompleks. Sebagai mata pencaharian untuk sebagian besar masyarakat di Sulawesi Selatan, praktik budi daya padi sebenarnya sudah mengakar sejak lama dan diusahakan di berbagai tempat. Dengan kondisi tanah yang relatif cocok untuk budi daya padi, keberadaan sungai-sungai, dan perbedaan masa panen, Sulawesi Selatan kemudian mampu berkembang sebagai lumbung beras utama di Groote Oost selama 1930-an. Karena dominannya faktor lingkungan tersebut, kedudukan penting sebagai penghasil beras hanyalah bentuk kontinuitas dalam proses sejarah Sulawesi Selatan. Meskipun demikian, adanya perbedaan karakteristik di beberapa tempat dan program intensifikasi pertanian justru memperlihatkan adanya perubahan produksi pertanian di Sulawesi Selatan. Sepanjang dekade terakhir pemerintahan kolonial, area utama produksi beras berasal dari Sidenreng, Rappang, Pinrang, Wajo, dan Soppeng.

Selain itu, perniagaan beras yang berlangsung di Sulawesi Selatan saat itu terkait erat dengan campur tangan negara sejak 1933. Keterkaitan ini tercermin dari langkah-langkah yang diterapkan pemerintah kolonial, 
mulai dari regulasi, kualitas beras, masalah harga, pengemasan, hingga pengangkutan. Berbagai langkah tersebut telah menyentuh perbaikan sistem perdagangan beras. Bahkan, keterlibatan negara juga telah memengaruhi jumlah beras yang diekspor. Angka ekspor yang melampaui daerah Bali dan Lombok, sekiranya menjelaskan peran Sulawesi Selatan sebagai lumbung beras utama di Groote Oost dan salah satu penyuplai beras penting di daerah luar Jawa, terutama selama 1930-an.

Jaringan perniagaan beras di Sulawesi Selatan turut menegaskan kedudukan istimewa tersebut. Dengan menggunakan kapal uap milik KPM dan perahu layar milik pribumi, komoditas beras dikapalkan ke berbagai daerah seberang, seperti Kalimantan Timur dan Selatan, Manado, Maluku, Timor, dan Jawa. Luasnya jaringan perniagaan itu juga memengaruhi dinamika pelabuhan di Sulawesi Selatan, sebagaimana tampak dari aktivitas pelayaran dan perniagaan di pelabuhan Parepare. Kasus Sulawesi Selatan juga memperlihatkan bahwa selama 1930-an pasar beras domestik sebenarnya tidak terputus sama sekali dengan pasar beras internasional, sebagaimana tampak dari impor beras asing di Manado pada 1934.

\section{DAFTAR SUMBER}

Ahmad, Taufik dan Syahrir Kila. 2016. Awal Kebangkitan \& Keruntuhan Pelabuhan Pallime di Bone. Makassar: Pustaka Refleksi.
Vol. 4, No. 2, Juni 2021, hlm. 113-140

An, Wu Xiau. 2011. "Rice Trade and Chinese Rice Millers in the LateNineteenth and Early-Twentieth Centuries: The Case of British Malaya". H1m. 336-59 dalam Chinese circulations: capital, commodities, and networks in Southeast Asia, disunting oleh E. Tagliacozzo dan W.C. Chang. Durham [N.C.]: Duke University Press.

Anon. 1919a. "Celebes En Onderhoorigheden." Bataviaasch Nieuwsblad, Oktober 19, 1.

Anon. 1919b. "Opgave van Het Gouvernement Celebes En Onderhoorigheden over September 1918." De Indische Mercuur, April 11,5 .

Anon. 1924. "Mooi Werk Op Celebes." Bataviaasch Nieuwsblad, April 22, 1.

Anon. 1931. Jaarverslag van de Handelsvereeniging Makassar over 1930. Makassar: CelebesDrukkerij.

Anon. 1933a. "Kabar dari KPM." Pemberita Makassar, Oktober 13, 1.

Anon. 1933b. "Keadaan Beras di Makassar." Pemberita Makassar, November 27, 1.

Anon. 1933c. "Perdagangan Beras di Parepare." Pemberita Makassar, November 11, 1.

Anon. 1933d. "Rijst Op Celebes." Bataviaasch Nieuwsblad, Agustus 9,1 
Anon. 1933e. "Rijstpellerijen Zuid-Celebes." Bataviaasch Nieuwsblad, Desember 28, 2.

Anon. 1933f. Staatsblad 1933, No. 300.

Anon. 1933g. "Surplus Beras dari Celebes." Pemberita Makassar, Agustus 1, 1.

Anon. 1933 h. "Welvaarts Bevordering." Bataviaasch Nieuwsblad, September 18, 1.

Anon. 1934a. "De Rijstsituatie." Bataviaasch Nieuwsblad, Juli 3, 1.

Anon. 1934b. "De Rijstsituatie." Soerabaijasch Handelsblad, Juli $21,11$.

Anon. 1935a. Jaarverslag van de Handelsvereeniging Makassar over 1934. Makassar: CelebesDrukkerij.

Anon. 1935b. "Verbetering van Lombokrijst." Bataviaasch Nieuwsblad, Agustus 8, 2.

Anon. 1939. Handelsvereeniging Exporteursvereeniging Makassar, Jaarverslag over 1938. Makassar: Celebes-Drukkerij.

Anon. 1941. Jaarverslag van de Handelsvereeniging Exporteurs Vereniging Makassar over 1940. Makassar: Celebes-Drukkerij.

Anon. 1945. Allied Geographical Section Southwest Pacific Area, Special Report No. 80, Makassar (SW Celebes), Dates 24 August 1945.
Anon. 2020. "Catat! 10 Provinsi yang Jadi Lumbung Beras di RI." Diunduh 17 April 2021 (https:// www.cnbcindonesia.com/news/ 20200623171209-51-167468/ catat-10-provinsi-yang-jadilumbung-beras-di-ri).

ANRI. 1911. Koloniaal Verslag.

ANRI. 1923. Koloniaal Verslag.

ANRI. 1924. Koloniaal Verslag.

ANRI. 1925. Koloniaal Verslag.

ANRI. 1926. Koloniaal Verslag.

ANRI. 1929. Koloniaal Verslag.

ANRI. 1931. Indisch Verslag.

ANRI. 1938. Indisch Verslag.

Arasaratnam, S. 1988. "The Rice Trade in Eastern India 1650-1740." Modern Asian Studies 22(3): 531-49.

Asba, Abdul Rasyid. 2003. "Ekspansi dan Kontraksi Ekspor Kopra Makassar 1883-1958." Disertasi, Fakultas Ilmu Budaya, Universitas Indonesia, Depok.

Beukering, J. A. van. 1935. "De Rijstsituatie in Zuid-Celebes." Economisch Weekblad Voor Nederlandsch-Indie, Desember, 1263-65.

Broersma, R. 1925. "De Uitvoerhandel van Makassar." Tijdschrift Voor Economische Geographie 16(4):97-101.

Bulbeck, David dan Ian Caldwell. 2008. "Oryza Sativa and the Origins of 
Handep Jurnal Sejarah dan Budaya Vol. 4, No. 2, Juni 2021, hlm. 113-140

Kingdoms in South Sulawesi, Indonesia: Evidence from Rice Husk Phytoliths." Indonesia and the Malay World 36(104):1-20.

Buuren, J. A. M. van. 1911. Irrigatie Rapport van Celebes.

Caron, L. J. J. 1933. Memorie van Overgave van Den Afgetreden Gouverneur van Celebes En Onderhoorigheden.

Cortesao, Armando. 2015. Suma Oriental Karya Tome Pires: Perjalanan dari Laut Merah ke Cina \& Buku Francisco Rodrigues. Yogyakarta: Ombak.

Dick, H. W. 1988. "Perdagangan Antar Pulau, Pengintegrasian Ekonomi dan Timbulnya Suatu Perekonomian Nasional." Hlm. 399-434 dalam Sejarah Ekonomi Indonesia, disunting oleh A. Booth, W. J. O. Malley, dan A. Weidemann. Jakarta: LP3ES.

Dick, Howard. 1990. The Indonesian Interisland Shipping Industry: An Analysis of Competition and Regulation. Pasir Panjang, Singapore: Institute of Southeast Asian Studies.

Eng, Pierre van der. 1996. Agricultural Growth in Indonesia: Productivity Change and Policy Impact since 1880. New York: St. Martin's Press.

Eng, Pierre van der. 2000. "Food for Growth: Trends in Indonesia's Food Supply, 1880-1995." The Journal of Interdisciplinary History 30(4):591-616.
Furnivall, J. S. 2009. Hindia Belanda: Studi tentang Ekonomi Majemuk. Jakarta: Freedom Institute.

Gottschalk, Louis. 1985. Mengerti Sejarah (Nugroho Notosusanto, Trans). Jakarta: Penerbit Universitas Indonesia.

Hamid, A. R. 2019. “Jaringan Maritim Mandar: Studi tentang Pelabuhan 'Kembar' Pambauwang dan Majene di Selat Makassar 19001980." Disertasi, Fakultas Ilmu Budaya, Universitas Indonesia, Depok.

Harvey, Barbara S. 1989. Pemberontakan Kahar Muzakkar: Dari Tradisi ke DI/TII. Jakarta: Pustaka Utama Grafiti.

Heringa, J. W. Th. 1933. Memorie van Overgave van Den Aftredenden Assistent Resident van Bone.

Heyting, Th. A. L. 1915. Memorie van Overgave van Den Aftredende Gouverneur van Celebes En Onderhoorigheden.

Ihsanuddin. 2019. “Jokowi Tunjuk Syahrul Yasin Limpo Jadi Menteri Pertanian." Diunduh 17 April 2021 (https://nasional.kompas.com/read/ 2019/10/23/09272001/jokowitunjuk-syahrul-yasin-limpo-jadimenteri-pertanian).

Ijzereef, Wilhelmus Theodorus. 1994. "De Wind En de Bladeren: Hierarchie En Autonomie InBone En Polombangkeng (ZuidSulawesi) 1850-1950." Disertasi, Rijksuniversiteit Groningen, Groningen. 
Kano, Hiroyoshi. 2008. Indonesian Exports, Peasant Agriculture and the World Economy, 1850-2000: Economic Structures in a Southeast Asian State. Singapore: NUS Press.

Laag, C. H. Ter. 1941. Memorie van Overgave van Den Resident van Celebes En Onderhoorigheden.

Lapian, Adrian B. 2009. Orang LautBajak Laut-Raja Laut: Sejarah Kawasan Laut Sulawesi Abad XIX. Depok: Komunitas Bambu.

Lee, Seung-Joon. 2017. "Rice and Maritime Modernity: The Modern Chinese State and the South China Sea Rice Trade." H1m. 99-117 dalam Rice: Global Networks and New Histories, disunting oleh F. Bray, P. A. Coclanis, E. L. F. Black, dan D. Schafer. New York: Cambridge University Press.

Macknight, C. C. 1983. "The Rise of Agriculture in South Sulawesi before 1600." Review of Indonesian and Malaysian Affairs 17:92-116.

Mansvelt, W. M. F. 1978. Changing Economy in Indonesia: A Selection of Statistical Source Material from the Early 19th Century up to 1940 Volume 4 Rice Prices. The Hague: Nijhoff.

Mey, M. D. 1935. Memorie va Overgave van de Onderafdeeling Pinrang, Afdeeling Parepare.

Moeljono, Sidik. 1971. Seperempat Abad Bergulat dengan Butir-Butir Beras. Djakarta: Bulog.
Mulya, A. A. Adi. 2017. "Dampak Revolusi Hijau di Sulawesi Selatan 1969-1998." Tesis, Universitas Indonesia, Depok.

Musyaqqat, Syafaat Rahman. 2020. "Antara Kuasa Negara dan Warisan Jalur Rempah: Perdagangan Beras di Sulawesi Selatan pada Dekade 1930-an." Prosiding, International Conference On Indonesia Culture (ICONIC 2020), Kementerian Pendidikan dan Kebudayaan, Jakarta:.

Musyaqqat, Syafaat Rahman. dan Didik Pradjoko. 2020. "The Role of Parepare Port in Trading and Shipping of Rice Commodities in South Sulawesi, 1930-1942." Journal of Maritime Studies and National Integration 4(2):115-26.

Musyaqqat, Syafaat Rahman. dan Nurfadilah Fajri Rahman. 2020. "Menelisik Aktivitas Pariwisata di Sulawesi Selatan pada Masa Kolonial (1929-1942)." Historia 8(2):145-62.

Nur, Nahdia. 2003. "Perdagangan Beras di Makassar Awal Abad XX." Lembaran Sejarah 5(1):83-94.

Nur, Nahdia. 2017. “Jejaring Perdagangan dan Integrasi Ekonomi: Sejarah Ekonomi Sulawesi Bagian Selatan 19021930-an." Disertasi, Program Studi S3 Ilmu Humaniora, Universitas Gadjah Mada, Yogyakarta.

Pelras, Christian. 2006. Manusia Bugis (A.R. Abu, Trans.). Jakarta: Nalar. 
Handep Jurnal Sejarah dan Budaya

Poelinggomang, Edward L. 2004.

Vol. 4, No. 2, Juni 2021, hlm. 113-140

Perubahan Politik dan Hubungan

Kekuasaan Makassar 1906-1942.

Yogyakarta: Ombak.

Poelinggomang, Edward L. 2016. Makassar Abad XIX: Studi tentang Kebijakan Perdagangan Maritim. Jakarta: KPG.

Poelinggomang, Edward L., Suriadi Mappangara, Suriadi Limbugau, Syahrul Amar, dan Sahajuddin. 2005. Sejarah Sulawesi Selatan (Jilid 2). Makassar: Balitbangda MSI Sulawesi Selatan.

Pradadimara, Dias. 2016. "Satu Cerita Berbeda tentang Krisis: Perubahan dan Transformasi di Wilayah Pedesaan Sulawesi Selatan pada Abad ke-20." Hlm. 199-219 dalam Dari Krisis ke Krisis: Masyarakat Indonesia Menghadapi Resesi Ekonomi Selama Abad 20, disunting oleh B. White dan P. Boomgaard. Yogyakarta: Gadjah Mada University Press.

Prince, G. H. A. 2000. "Kebijakan Ekonomi di Indonesia, 19001942." Hlm. 226-56 dalam Sejarah Ekonomi Modern Indonesia: Berbagai Tantangan Baru, disunting oleh J. T. Lindblad. Jakarta: LP3ES.

Reid, Anthony. 2004. Sejarah Modern Awal Asia Tenggara. Jakarta: LP3ES.

Saraber, F. H. 1929. "De Wereldproductie van Mais En Die van Zuid-West Celebes in $\mathrm{T}$ Bijzonder." Tijdschrift Voor

Economische

Geographie 20(11):434-37.

Schimmel, G. J. 1937. "De Rijstpolitiek in de Jaren 1933 Tot 1937." Landbouw 13:156-72.

Sulistyono, Singgih Tri. 2001. "Perahu Shipping Around the Java Sea and Its Role in the Interregional Connection During the Late Colonial State of Indonesia, 19001942." Hlm. 203-28 dalam Arung Samudera: Persembahan Memperingati Sembilan Windu A.B. Lapian, disunting oleh E. Sedyawati dan S. Zuhdi. Depok: Lembaga Penelitian Universitas Indonesia-Yayasan Adikarya IKAPI.

Sutherland, Heather. 2015. "On the Edge of Asia: Maritime Trade in East Indonesia, Early Seventeenth to Mid-Twentieth Century." Hlm. 59-78 dalam Commodities, Ports and Asian Maritime Trade Since 1750, disunting oleh U. Bosma dan A. Webster. Houndmills: Palgrave Macmillan.

Swaab, J. L. M. 1936. Memorie van Overgave van Den Afgetreden Gouverneur Celebes En Onderhoorigheden.

Touwen, Jeroen. 2001. Extremes in the Archipelago: Trade and Economic Development in the Outer Islands of Indonesia 1900-1941. Leiden: KITLV Press.

Universitaire Bibliotheken Leiden. 1920. "Schetskaart van Zuid-WestCelebes." Diunduh 17 April 2021 (https://digitalcollections. 
universiteitleiden.nl/view/item/

815176?solr_nav $\% 5 \mathrm{Bid} \% 5 \mathrm{D}=0 \mathrm{ec} 63 \mathrm{c} 5$

ce 9 c $4208 \mathrm{fb} 782$ \& solr_nav

$\% 5 \mathrm{Bpage} \% 5 \mathrm{D}=0 \&$ solr_nav $\% 5$

Boffset $\% 5 \mathrm{D}=17$ ).

Vorstman, F. 1911. "Het Gouvernement Celebes En Onderhoorigheden En Zijn Hoofdplaats Makassar." Tijdschrift Voor Economische Geographie 2(12):379-92.

Vorstman, F. 1924. Memorie van Den Gouverneur van Selebes En Onderhoorigheden.

Vuuren, L. Van. 1922. "Koloniale Landbeschrijving." Tijdschrift Voor Economische Geographie 13(2):52-66.

Wirawan, Yerry. 2013. Sejarah Masyarakat Tionghoa Makassar dari Abad ke-17 Hingga Ke-20. Jakarta: KPG. 

Vol. 4, No. 2, Juni 2021, hlm. 113-140 